\title{
TITLE:
}

\section{Two Memories of Nishida-san in Tanzania}

\author{
$\operatorname{AUTHOR}(\mathrm{S})$ :
}

Hanamura, Shunkichi

\section{CITATION:}

Hanamura, Shunkichi. Two Memories of Nishida-san in Tanzania. Pan Africa News 2011, 18(special issue): 12-12

ISSUE DATE:

2011-09

URL:

http://hdl.handle.net/2433/147274

\section{RIGHT:}

Copyright (C) Pan Africa News. 
attended my lecture". As soon as I explained that I would like to study the paternity of Japanese macaques using DNA, he accepted my topic. In the laboratory, there was no experiment room, so he contacted the late Prof. Takenaka, who was one of the pioneers to develop the genetic markers for kinship analyses in primates. Thanks to them, I now study wild animals using behavioral and genetic analyses.

After I finished the paternity analyses of Japanese macaques, he invited me to research chimpanzees in Mahale. Although I did not have a strong yearning for research in Africa, I decided to join his project. His invitation opened the doors to research wild animals in Africa for me. My first visit to the Mahale forest was accompanied by Prof. Nishida. He gave me a lot of information on chimpanzees as well as names of plants they ate. It was just like introducing his family to me, and I was strongly struck by his love for the chimpanzees.

I was also impressed when I visited him with $\mathrm{Mr}$. Matsumoto, a student staying at Mahale now, a few years ago. He explained how fascinating the research on wild chimpanzees could be and showed us several research topics which he would like to study. It was amazing that he was still motivated after his decades of great works. He had inexhaustible energy and passion with many interesting ideas. I can still remember his happy face when he talked about research on chimpanzees. I would like to continue my research, emulating his motivation for research and keeping various advices from him in mind.

Finally, I sincerely pray for him to rest in peace.

\section{Two Memories of Nishida-san in Tanzania}

\section{Shunkichi Hanamura \\ Kyoto University, Japan}

In October 15, 2005, for my first chimpanzee research at Mahale, which was my cherished wish, I flew to Dar es Salaam, Tanzania. Because this travel was my first and solo foreign travel, I got excited and nervous. At that place, I met Nishida-san, who had just left from Mahale, and he gave a feast for me in his favorite "New Africa Hotel." During the dinner, he kept telling many funny stories about chimpanzees like a human comedic drama in his own swinging tempo. The talk helped relieve a lot of my tension about this travel by the time we said farewell.

In July 31, 2006, Nishida-san planned to arrive at Mahale again. By that time, I was used to the field and was devoted to my study on the chimpanzees. I was looking forward to walking with him in the Kasoge forest. Our research hut in Kansyana Camp which had collapsed in an earthquake was rebuilt in time for his arrival. The next day, however, I got a message that he postponed his trip owing to bad health. Thinking back now, this might have been the beginning of his cancer which was found out that October. From some days before July 31, the M-group chimpanzees began to gather but, from that day on, they dispersed again and I observed a few chimpanzees over the next several days. "Chimpanzees gathered to greet Mzee Nishida and dispersed in disappointment because they understood his absence," all our field assistants told me.

\section{Running Down a Steep Trail}

\author{
Agumi Inaba \\ Japan Monkey Centre, Japan
}

I am greatly indebted to Professor Nishida for the last ten years since 2001, when he hired me for a part-time job. Prof. Nishida fell ill during his official trip to Uganda in July 2006, and he was diagnosed with rectal cancer in October. He strongly regretted having overlooked the symptoms at an early stage. In June of the same year, we received the sad news from Mr. Hanamura, stayed at Mahale, that many M-group chimpanzees had died due to an outbreak of respiratory disease. "I was still prime when Chausiku disappeared (eaten by a lion in 1990)," he said, "but this time, I am greatly shocked and have lost the will to study after the disappearance of Opal, Miya, and Pinky." In August of the following year, 2007, I was given a chance to join him in the field. He was so energetic that I couldn't imagine he had undergone an operation at the end of the previous year. Once, he ran down a steep trail with some chimpanzees, blowing up a cloud of sand, and he left us behind in a matter of seconds. He said at the base of the mountain, "I never fell behind the chimpanzees!" He seemed to have recovered his self-confidence. However, the next year, his disease appeared to quickly advanced, and thus he began anti-cancer treatment. He concentrated on his work when he was in good shape, and then his last book, Chimpanzees of the Lakeshore was completed, accomplished through the dedicated cooperation of Prof. McGrew and others. Although I visited him frequently in his hospital room and his home to give his manuscript a final check, the last time I talked with him was on the telephone, two weeks before he passed away. I would like to thank Prof. Nishida for all that he gave us.

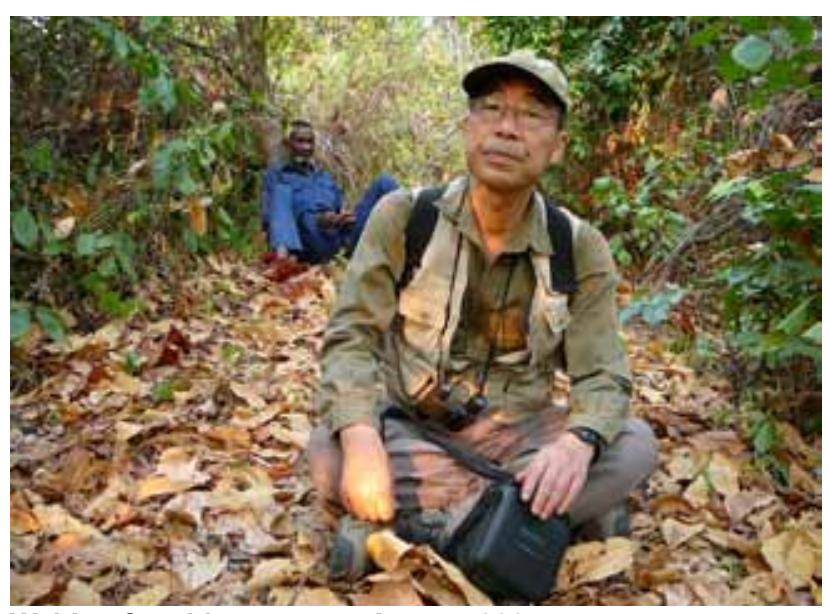

Waiting for chimpanzees, August 2007.

Pan Africa News, Vol. 18, special issue

Published in September, 2011

Address: c/o Human Evolution Studies,

Dept. of Zoology, Faculty of Science,

Kyoto Univ., Kyoto, 606-8502, JAPAN

TEL: $(+81) 75-753-4093$

FAX: $(+81) 75-753-4115$

E-mail: pan.editor@gmail.com

URL: http://mahale.main.jp/PAN/

ISSN: 1884-751X (Print), 1884-7528 (Online) 